


\section{The films of Costa-Gavras}

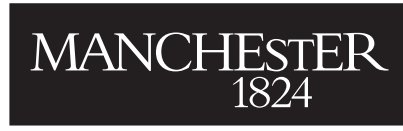

Manchester University Press 
Homer B. Pettey - 9781526146939 Downloaded from manchesterhive.com at 04/26/2023 11:30:55AM via free access 


\section{The films of Costa-Gavras}

New perspectives

Edited by Homer B. Pettey

Manchester University Press 
Manchester University Press 2020

While copyright in the volume as a whole is vested in Manchester University Press, copyright in individual chapters belongs to their respective authors, and no chapter may be reproduced wholly or in part without the express permission in writing of both author and publisher.

Published by Manchester University Press

Altrincham Street, Manchester M1 7JA

www.manchesteruniversitypress.co.uk

British Library Cataloguing-in-Publication Data

A catalogue record for this book is available from the British Library

ISBN 9781526146922 hardback

First published 2020

The publisher has no responsibility for the persistence or accuracy of URLs for any external or third-party internet websites referred to in this book, and does not guarantee that any content on such websites is, or will remain, accurate or appropriate.

Cover: Still from Costa-Gavras's Z (1969)

Typeset

by New Best-set Typesetters Ltd 